\title{
Schäden im Zusammenhang mit dem Schmelztauchverzinken
}

\section{Damage Caused by Hot Dip Galvanising}

\author{
Markus Zgraggen, Rolf Winkler, Markus Winkler*), Harald Germ*), Samuel Trüllinger, \\ Markus Faller, Oliver von Trzebiatowski
}

Korrespondenzanschrift/Correspondence address:

EMPA Dübendorf, Überlandstrasse 129, $\mathrm{CH}-8600$ Dübendorf

E-Mail: markus.zgraggen@empa.ch

*) Doppelmayr AG, A-6961 Wolfurt

Eingangen: 25. August 2005

Angenommen: 29. August 2005

\section{Kurzfassung}

Beim Schmelztauchverzinken von Stahlkonstruktionen kommt es immer wieder zu Schadensfällen. Die gesamte Fertigungskette hat auf das Schadensgeschehen letztlich einen Einfluss. Es liegt also häufig ein unglückliches Zusammenspiel verschiedener Einflussgrössen vor. Anhand vonSchadensuntersuchungen kann aufgezeigt werden, wo in der Fertigungskette optimiert werden kann, um solche Schäden zu vermeiden.

\section{Einleitung}

Im Stahlbau ist das Schmelztauchverzinken oder Feuerverzinken als Korrosionsschutz ein verbreitetes, anerkanntes Verfahren und wird entsprechend häufig angewandt. Immer wieder kommt es aber zu teilweise gravierenden Schadensfällen an feuerverzinkten Bauteilen. Teilweise handelt es sich um offensichtliche Schäden, wie beispielsweise das Aufreissen von Rohren oder Trägern. Diese Fälle sind noch verhältnismässig harmlos, da solche Teile auf Grund der sichtbaren Risse kaum zum Einsatz kommen. Wenn Anrisse jedoch unerkannt bleiben, ergibt sich eine potentielle Gefahr. Sie können Keime für Ermüdungsanrisse bilden oder es kommt beim Einbau plötzlich zum Bauteilversagen. Ein Ziel der Schadensanalyse ist, den rissauslösenden Mechanismus zu finden. Da das Feuerverzinken am Schluss der Prozesskette liegt, steht dann jeweils der Verzinkungsbetrieb im Zentrum des Verdachts, weil
Received: April 25, 2005

Accepted: April 29, 2005

Translation: Ph. Tate

\section{Abstract}

Failures repeatedly occur in the hot dip galvanising of structural steelwork, the appearance of which are directly influenced by the nature of the finishing process and which are often the result of an unexpected interaction between the various parameters and materials involved. The examination of such failures can indicate where the process can be improved in order to avoid future problems.

\section{Introduction}

In the structural steel industry, hot dip galvanising is a well known and widely used method of corrosion protection. Failures, in some cases with severe consequences, however repeatedly occur as a result of hot dip galvanising. Sometimes the failures are readily apparent such as in the cracking of pipes and beams, these cases being essentially harmless because the cracking is generally visible and the component is never used. If however such cracks remain undetected they can present a potential danger, acting either as nucleation points for fatigue cracks or more dangerously resulting in the immediate failure or collapse of the component during assembly or erection. The aim of the examination of such failures is to discover the cause and mechanism of crack initiation. Because hot dip galvanising is carried out at the end of the manufacturing process, the galvaniser is often regarded to have caused the damage 
die Bauteile vor dem Verzinken rissfrei waren. Schuldzuweisungen dieser Art sind natürlich ohne Überprüfung des Falls nicht korrekt. Die vorliegende Arbeit soll an Hand von Beispielen zeigen, wie eine detaillierte Schadensanalyse zur Ermittlung der Schadensursache dienen kann.

\section{Schadensuntersuchungen}

Bei der Fertigung von Kastenprofilen aus einem Stahl vom Typus S355J2G3 mit der Werkstoffnummer 1.0570 (St 52-3) wurden nach dem Feuerverzinken mittels zerstörungsfreier Prüfverfahren Risse festgestellt. Die für die Fertigung der Kastenprofile verwendeten Rohbleche werden bei verschiedenen Lieferanten mit diversen thermischen Schnittverfahren bearbeitet und anschliessend ohne weitere Bearbeitung der Schnittkanten verschweisst. Die gefügten Bauteile wurden anschliessend beica. $450{ }^{\circ} \mathrm{C}$ bei verschiedenen Verzinkungsbetrieben nach dem Tieftemperatur-Schmelztauchverfahren verzinkt. Da die Kastenprofile nach dem Schweissprozess rissgeprüft wurden und zu diesem Zeitpunkt keine Risse zeigten, kann davon ausgegangen werden, dass die Risse erst nach bzW. beim Feuerverzinken entstehen. Für die fraktographische Untersuchung wurden Anrisse geöffnet. An den Rissflanken ist keine plastische Verformung erkennbar und die frei-

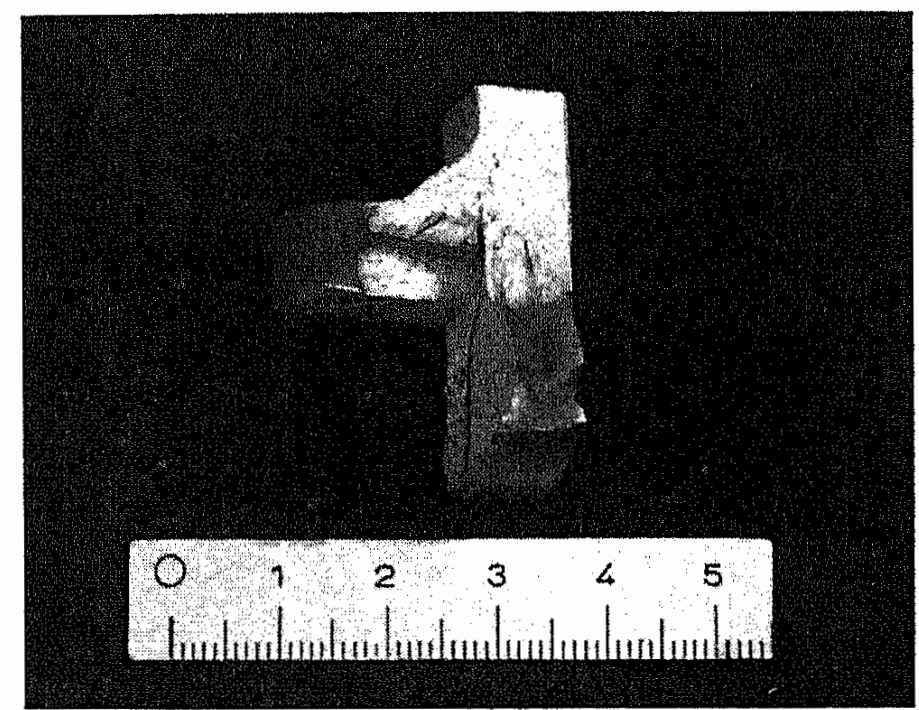

Bild 1. Freigelegter Riss mit Zinkbelag (hell)

Fig. 1. Crack broken open with zinc coated crack surfaces (light coloured) as prior to hot dip galvanising the components were free of cracks. The apportion of blame in this way is clearly however unjustified without first carrying out a proper examination of the cause of failure. With reference to a number of examples, this article demonstrates how the use of a detailed failure examination can serve to clarify the cause of failure.

\section{Failure Examinations}

In the finishing of box sections made of S355J2G3 steel (St 52-3) (Material No. 1.0570) cracks were found on non-destructive testing after hot dip galvanising. The plate used to fabricate the box sections was sourced from different suppliers using different methods of thermal cutting, the edges of the plates then being welded together without any further preparation of the cut edges. The box sections were subsequently coated at ca. $450^{\circ} \mathrm{C}$ using the low temperature hot dip galvanising technique by different galvanising companies. As the box sections had been non-destructively tested after the welding operation and had not revealed the presence of any cracks, it could be assumed that the cracks found had formed during or after the hot dip galvanising operation. A number of the cracks were broken open for fractographic examination. No plastic deformation was apparent along the edges of the cracks and the surfaces of the cracks were completely coated

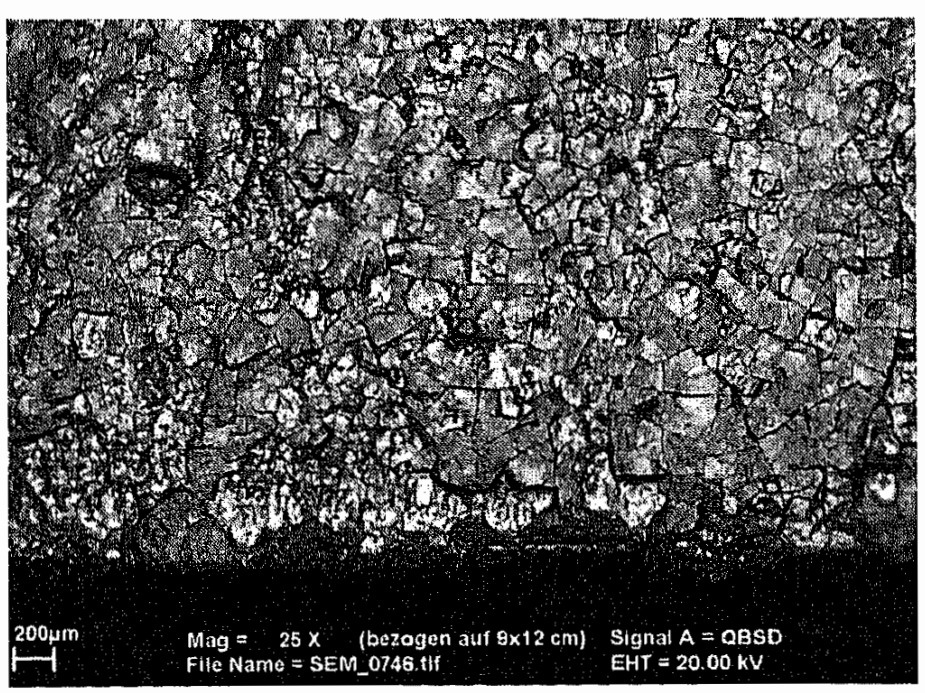

Bild 2. Vollständig mit Zink belegte Bruchfläche

Fig. 2. Fracture surface completely covered with zinc 
gelegten Anrisse sind durchwegs vollständig mit Zink belegt (Bild 1 und 2). Die Bruchflächencharakterisierung wird durch die Zinkbelegung entsprechend erschwert. Nach vorsichtigem Reinigen in $\mathrm{HCl} 10 \%$ ist eine Struktur mit interkristallinem Charakter auf den ehemals mit Zink belegten Trennflächen nachweisbar (Bild 3).

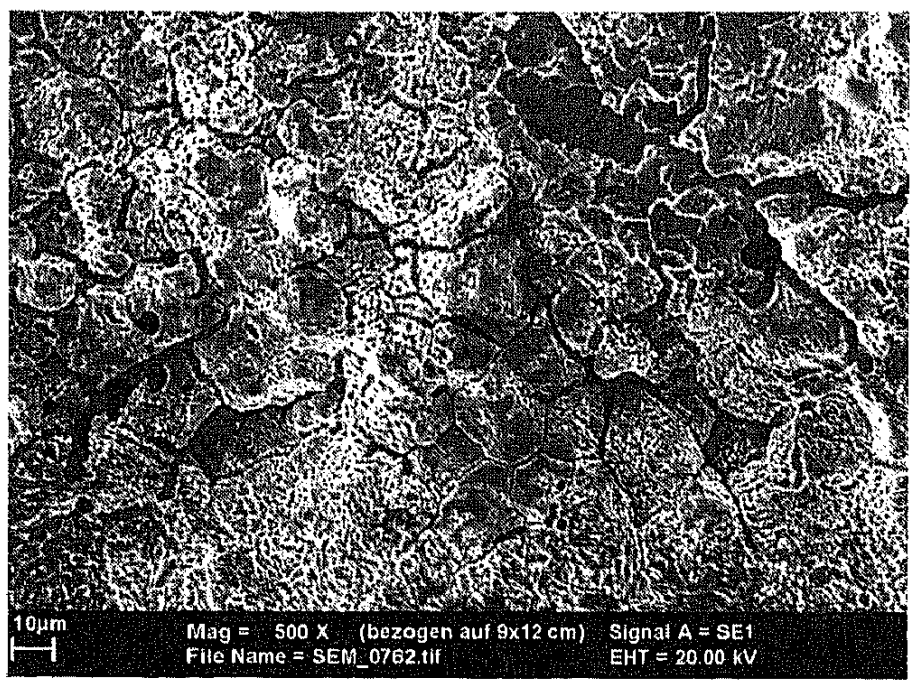

Bild 3. Gereinigte Bruchfläche, interkristalline Struktur

Fig. 3. Fracture surface after cleaning showing intercrystalline crack path

Bei der metallographischen Untersuchung connten zahlreiche, interkristallin verlaufenJe Nebenrisssysteme nachgewiesen werden (Bild 4). Im Rückstreuelektronenbild (Materialkontrast, Elemente höherer Ordnungszahl erscheinen hell) sind deutlich hell erscheinende Fremdmetallbelegungen auf den Korngrenzen feststellbar (Bild 5). Aus den mittels EDX aufgenommenen Elementverteilungsbildern wird

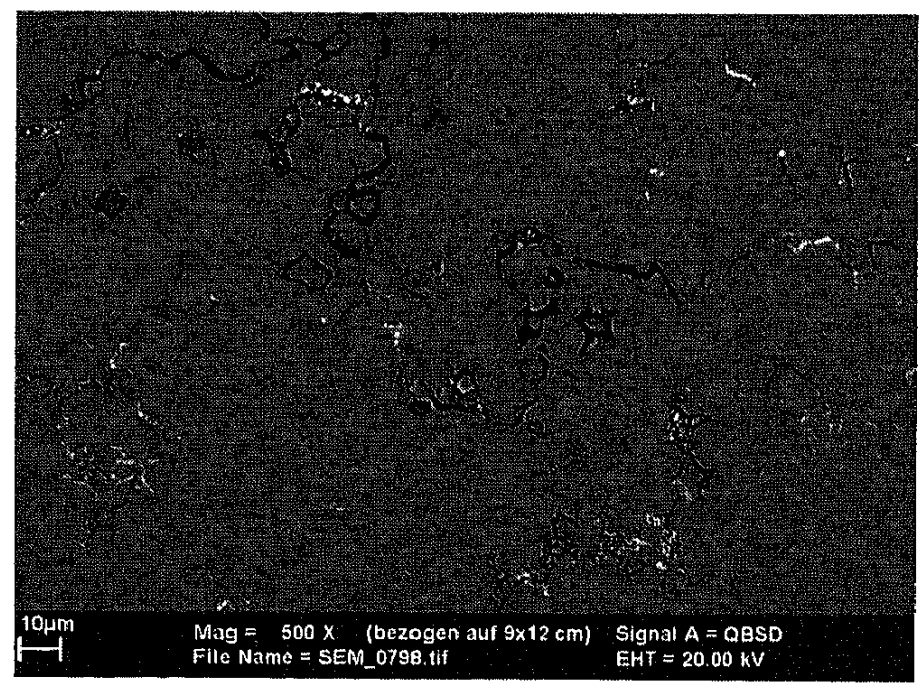

with zinc (Figs. 1 and 2), this making the characterisation of the fracture surfaces extremely difficult. After carefully removing the zinc with $10 \% \mathrm{HCl}$ however, the fracture surfaces previously coated with zinc were shown to exhibit an intercrystalline mode of fracture (Fig. 3).

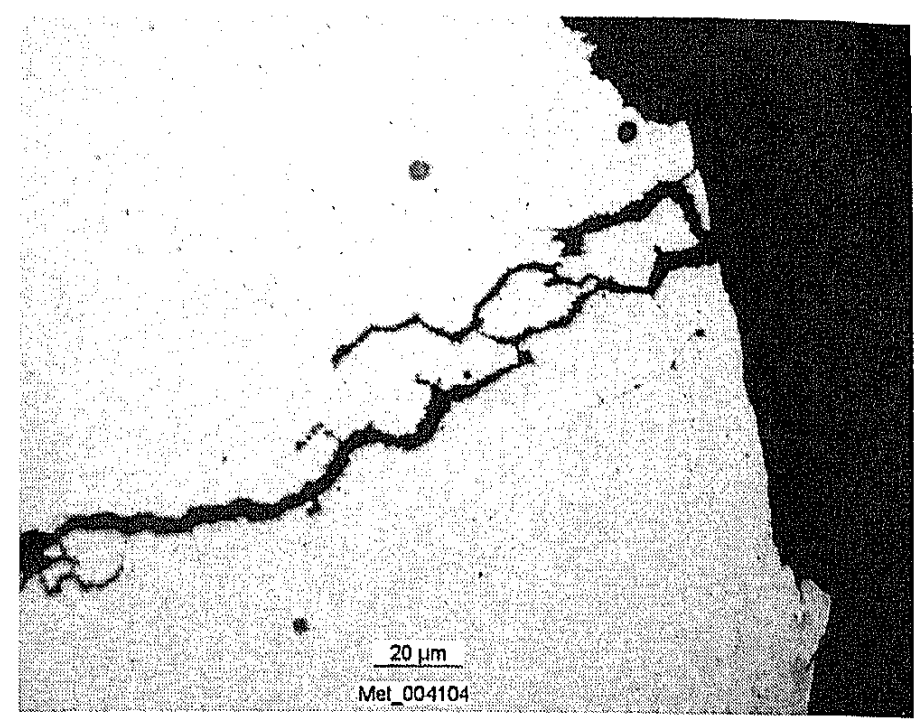

Bild 4. Interkristallin verlaufender Nebenriss

Fig. 4. Intercrystalline subsidiary crack

The metallographic investigation revealed the presence of numerous intercrystalline subsidiary crack systems (Fig. 4). In the back scattered electron image (in which the higher order elements appear brighter) bright foreign metallic coatings can be seen in the grain boundaries (Fig. 5). From the EDX element distribution maps it can be seen that the grain boundary coatings are zinc and tin and that the tin has

Bild 5. Rückstreuelektronenbild des interkristallinen Risssystems. Die Fremdmetalleinschlüsse erscheinen hell.

Fig. 5. Back scattered electron image of the intercrystalline crack system. The foreign metallic inclusions appear lightly coloured. 


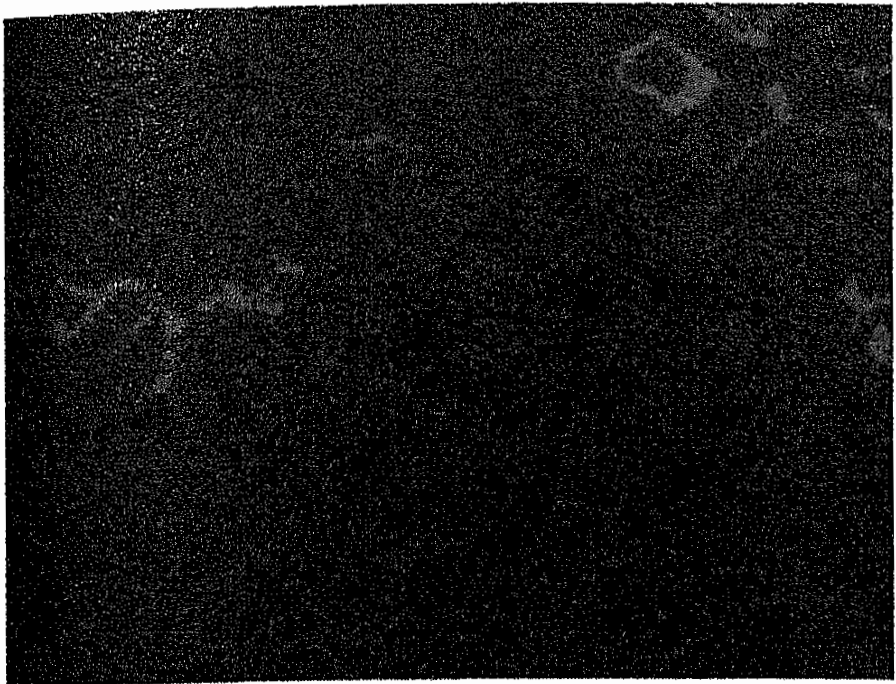

100um

Bild 6. EDX-Mapping, Zinkverteilung

Fig. 6. EDX-map, zinc distribution

ersichtlich, dass es sich beim Fremdmetall um Zink und Zinn handelt und das Zinn wesentlich tiefer in den Grundwerkstoff eindringt als das Zink (Bilder 6 und 7). Offensichtlich haben Bedingungen vorgeherrscht, die eine Flüssigmetallversprödung auslösten. Typisch für Flüssigmetallversprödung ist ein interkristalliner Rissverlauf, wobei die Risse meist mit Fremdmetall gefüllt sind. Flüssigmetallversprödung wird auch als Lötbrüchigkeit oder dehnungsinduzierte Spannungsrisskorrosion in Metallschmelzen bezeichnet. Als Bedingungen für das Auftreten derartiger Schäden werden in der Literatur [1,2] unter Anderem folgende Einflussgrössen genannt:

- die Schmelze oder deren Hauptbestandteil muss in dem festen Metall oder das letztere in der Schmelze löslich sein

- die Empfindlich keit auf Flüssigmetallkorrosion wächst mit der Korngrösse

- Zugspannungen fördern die Flüssigmetallkorrosion

- lange Tauchzeiten und hohe Temperaturen begünstigen den Angriff.

Da Stahlbauteile beim Feuerverzinken naturgemäss mit grossen Mengen Flüssigmetall in Berührung kommen, ist das Gefährdungspotenzial beim Verzinken entsprechend hoch. Bei die-

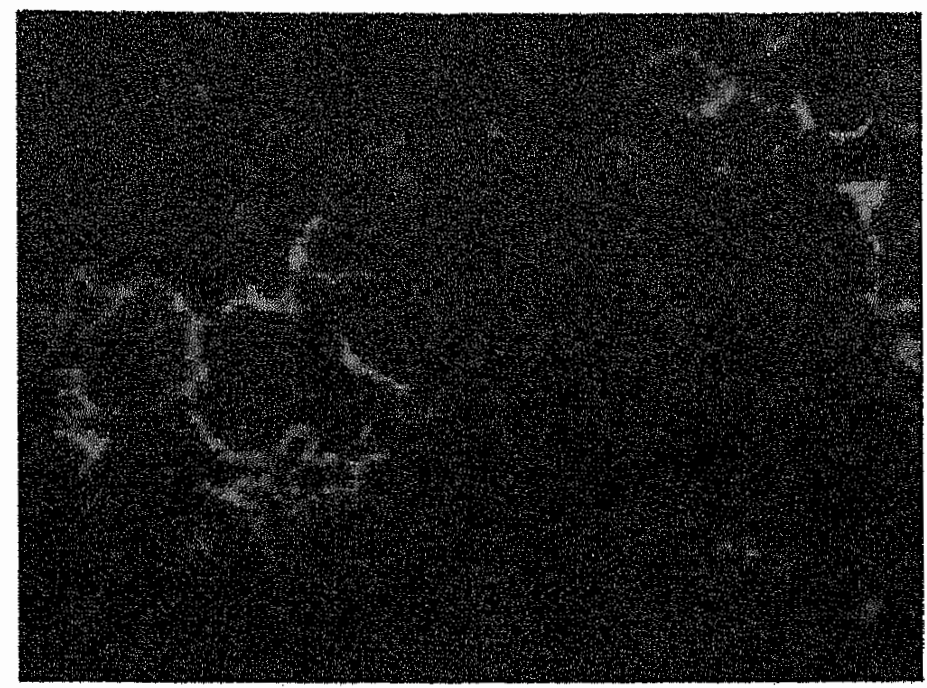

$100 \mu \mathrm{m}$

Bild 7. EDX-Mapping, Zinnverteilung

Fig. 7. EDX-map, tin distribution

penetrated considerably deeper into the base metal than the zinc (Figs. 6 and 7). From this it would appear that conditions must have been conducive to liquid metal embrittlement. Liquid metal embrittlement, also known as solder embrittlement or strain induced stress corrosion cracking in liquid metals, is characterised by exhibiting an intercrystalline crack path with the cracks generally filled with the foreign metal. In the literature $[1,2]$, the conditions for this type of damage to occur are listed as follows:

- The melt or its main components are soluble in the solid metal or the latter is soluble in the melt

- The sensitivity to liquid metal embrittlement increases with grain size

- Tensile stresses promote liquid metal embrittelment

- Long immersion times and high temperatures favour this type of attack.

Because structural steel components naturally come into contact with large quantities of liquid metal when being hot dip galvanised, the potential for such damage is high. In this particular 




Bild 8. Zinkschicht mit ausgeprägten Fremdmetalleinschlüssen (hell)

Fig. 8. Zinc coating with marked foreign metallic inclusions (light coloured)

sem Schadensfall war der Hauptfehler effektiv beim Verzinken zu suchen. Bei einem Vergleich der Badanalysen und der Zinkschichtuntersuchungen konnte eine markante Häufung von Schadensfällen in Verzinkungsbetrieben mit vergleichsweise hohen Zinn- und Bleigehalten nachgewiesen werden. Für sich alleine betrachtet reagieren die Elemente Zinn und Blei relativ träge mit dem Stahl, in Kombination zusammen mit dem Zink wirkt jedoch die Schmelze zunehmend aggressiver $[1,3,4]$. Für eine Abschätzung der Begleitelementgehalte in den Beschichtungen bietet sich die Untersuchung metallographischer Anschliffpräparate mittels Rückstreuelektronendetektor an (Bild 8 und 9). Die Charakterisierung der Zinkschichten auf den Schadensteilen ist auch deshalb von Bedeutung, weil bei ungünstiger Prozessführung beim Verzinken Verunreinigungen, also insbesondere Zinn und Blei, aus dem Badsumpf aufgewirbelt werden können. Die Schöpfanalyse der Zinkbäder kann also durchaus tiefe Blei- und Zinngehalte aufweisen, weil die Probe aus einem "sauberen“ Badbereich entnommen wurde.

Dass auch in hochreinen Zinkbädern Schäden auftreten können, zeigt das zweite Beispiel. Mehrere kaltverformte Träger aus dem Werkstoff S355 sind regelrecht aufgesprungen (Bild 10). Auch hier liess sich metallographisch ein ähnliches Erscheinungsbild wie beim ersten Fall

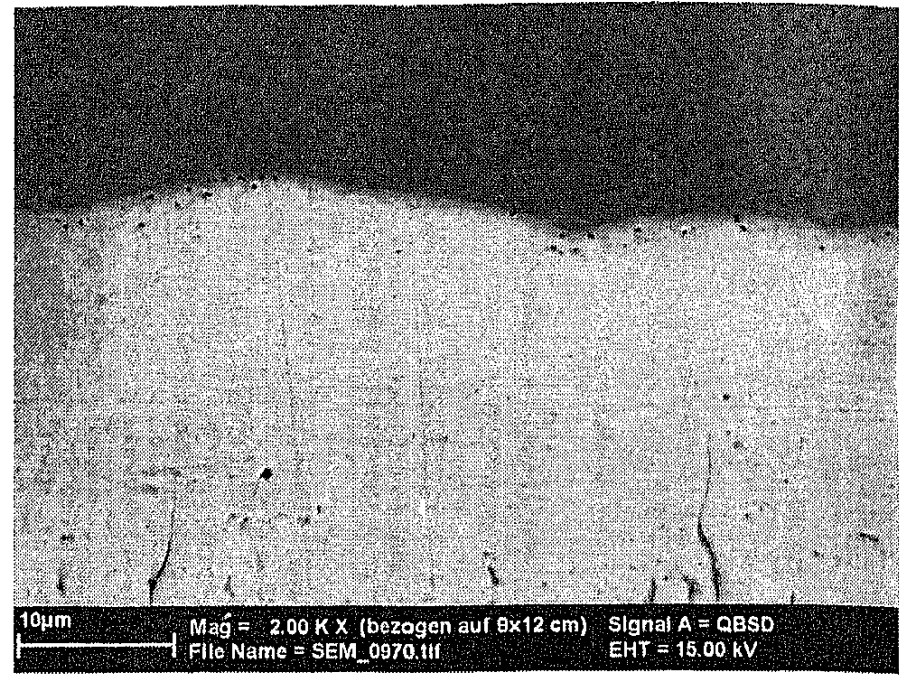

Bild 9. Referenzzinkschicht mit sehr wenigen Fremdmetalleinschlüssen

Fig. 9. Reference zinc coating with very few foreign metallic inclusions

failure examination, the main cause was effectively be found in the galvanising process. A comparison of the bath analyses and zinc coatings revealed that a similarly high occurrence of this type of failure had been experienced in all galvanising firms using similarly high levels of tin and lead. On their own, the elements tin and lead react relatively innocuously with steel. In combination with zinc however, the melt reacts increasingly more aggresively $[1,3,4]$. In order to determine the content of these elements in the coatings the metallographically prepared cross sections of the coatings were analysed using a back scattered electron detector (Figs. 8 and 9). A characterisation of the zinc coatings at the point of failure is also important because in the case of poor process control during galvanising, impurities, in particular tin and lead, can be disturbed and caused to rise up into the melt from the bath sump where they accumulate. An analysis of the bath can thus show quite low levels of tin and lead as the sample will almost always be taken from a relatively clean shallow region of the bath.

The second example demonstrates that failures can also occur in high purity zinc baths. A number of cold formed beams made of the steel S355 were observed to have split severely after galvanising (Fig. 10). Here also, initially a similar picture to that described previously was 
feststellen. Allerdings sind die Risse kaum mit Zink gefüllt und verlaufen grösstenteils transkristallin (Bild 11). Daraus lässt sich ableiten, dass die Spannungen in diesem Fall überwogen und der Angriff durch die Metallschmelze selbst eine untergeordnete Rolle spielte. An sich wurde auch hier der Riss durch die Zinkschmelze eingeleitet, der primäre Fehler ist jedoch bei der Höhe der Eigenspannungen zu suchen. Insbesondere auch deshalb, weil eine zweite Serie artgleicher Werkstücke ohne Probleme im gleichen Bad verzinkt werden konnte. Bei der Sichtung der Unterlagen stellte sich heraus, dass der Werkstoff bei den Schadensteilen bis zu 0,5\% Kupfer enthielt. Kupfer erhöht die Festigkeit und Streckgrenze. Bei Kaltverformungen unter gleich bleibenden Umformbedingungen ist somit mit beträchtlich höheren Eigenspannungen im Bauteil zu rechnen als bei kupferfreien Werkstoffen.

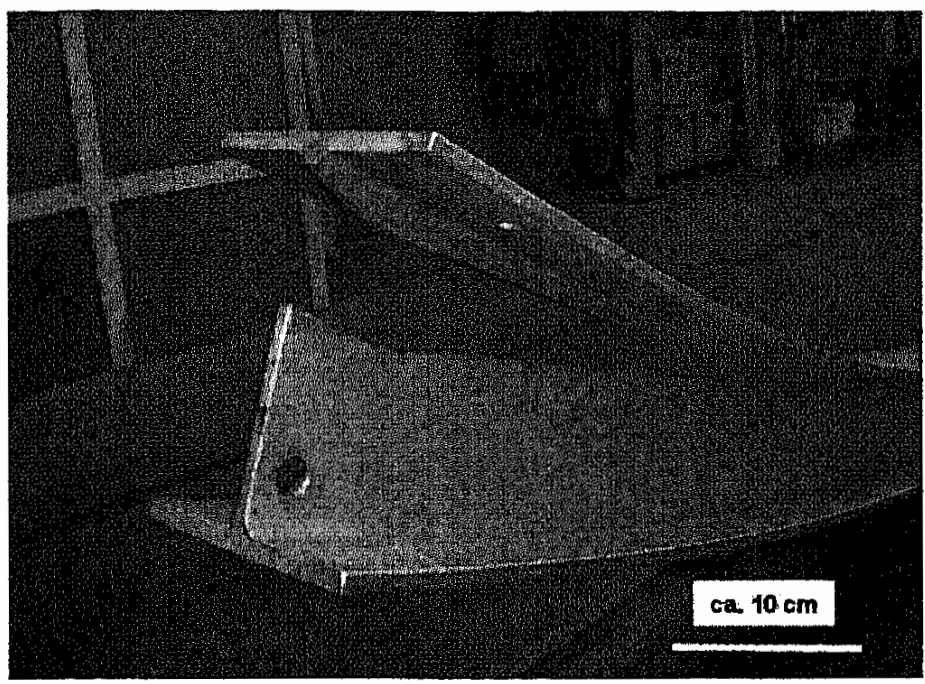

Bild 10. Beim Verzinken aufgerissener Träger

Fig. 10. Beam cracked during galvanising

Beim dritten Fall traten an kaltverformten Hohlprofilen beim Einbau der Bauteile Risse auf (Bild 12). Die fraktographische Untersuchung hat gezeigt, dass die Risse von innen ausgehen. Auf geöffneten Rissflanken kann eingedrungenes Zink mittels EDX nachgewiesen werden (Bild obtained from the metallographic examination. In this case however the cracks were observed to contain hardly any zinc and the crack path was mostly trans-crystalling (Fig. 11). From this it could be deduced that in this case the stresses were of greatest influence and that the attack by the liquid metal itself played only a subordinate role. In principle, here also, the crack was initiated by the molten zinc. The primary cause of failure however was to be sought in the high internal stresses within the structural component. This was clear because a second series of similar beams were subsequently galvanised in the same bath without any such problems. On examining the documentation it was discovered that the steel used in the case of the split beams contained up to $0.5 \%$ copper. Copper increases the tensile strength and yield point of steels, thus on cold working, under otherwise identical conditions of forming, considerably higher internal stresses will be induced in the components fabricated from the steel with the higher copper than in those from the copper free materials.

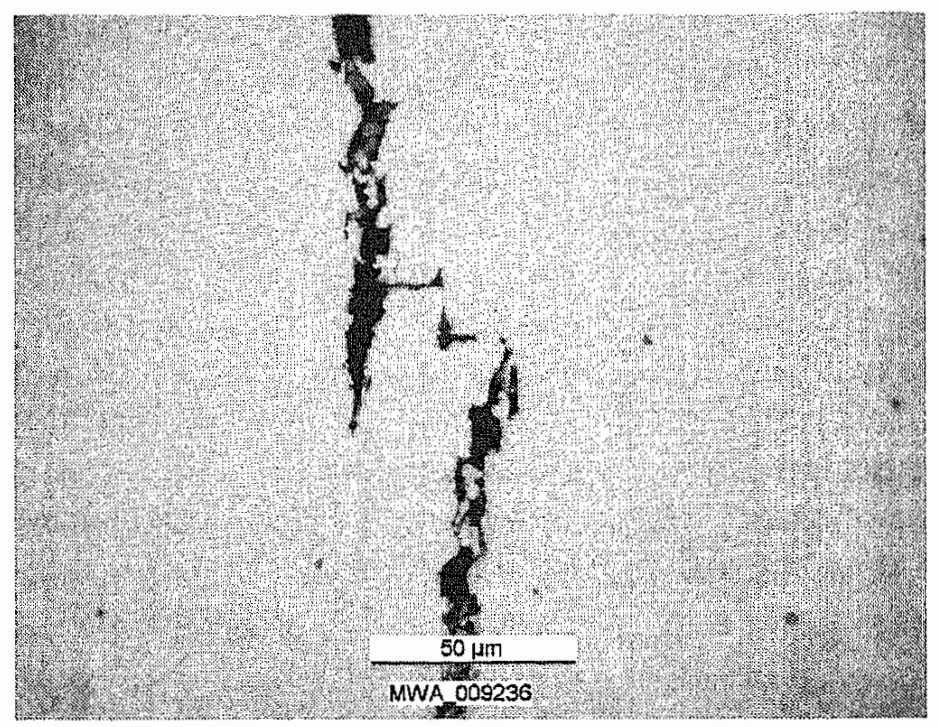

Bild 11. Grösstenteils transkristalliner Rissverlauf ohne Fremdmetalleinschluss

Fig. 11. Mainly trans-crystalline crack path without foreign metallic inclusions

In the third case cracks formed during the assembly of a structure of cold formed hollow profiles (Fig. 12). The fractographic examination revealed that the cracks had grown from the inside of the profiles. Using EDX analysis it was shown that zinc had penetrated into the flanks 

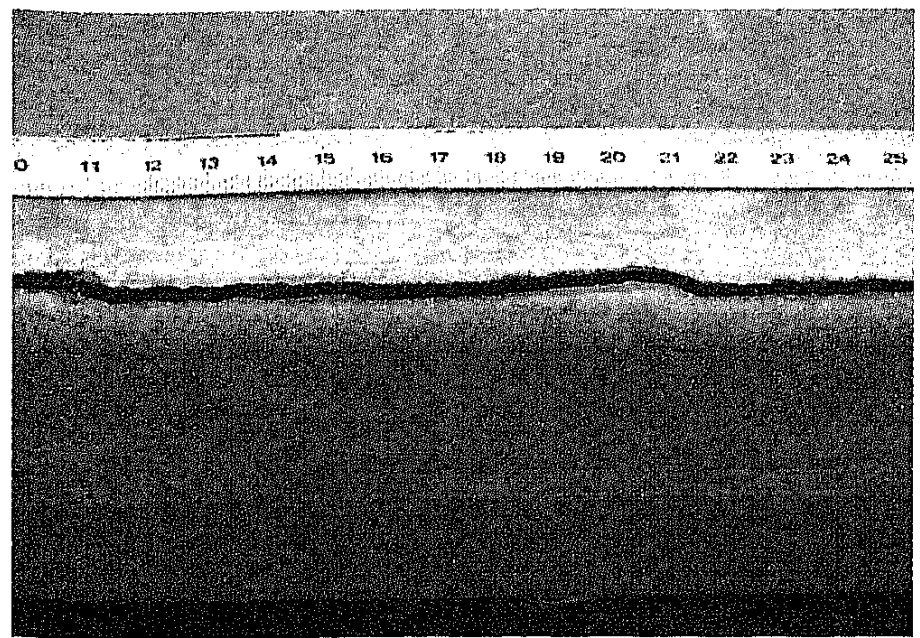

Bild 12. Riss in einem Hohlprofil

Fig. 12. Crack in a hollow section

13). Zusätzlich zeigt die Zinkschicht einen Saum mit Zinn und Blei (Bild 14), allerdings wesentlich weniger ausgeprägt als beim Fall 1 (vergleiche Bild 8). Der vorliegende Werkstoff, wieder ein S355, enthielt lediglich 0,1\% Kupfer. Das im Fall 2 erwähnte Zusammenspiel zwischen Kupfergehalt und höherer Festigkeit bzw. Eigenspannungen spielt somit in diesem Fall kaum eine Rolle. Durch die Konstruktionsweise mit beidseitigen Abschlüssen ergaben sich, trotz der für das Verzinken notwendigen Bohrungen, lange Tauchzeiten. Die normalerweise unkritischen Anteile an Verunreinigungen konnten so entsprechend lange einwirken und die Flüssigmetallversprödung verursachen.

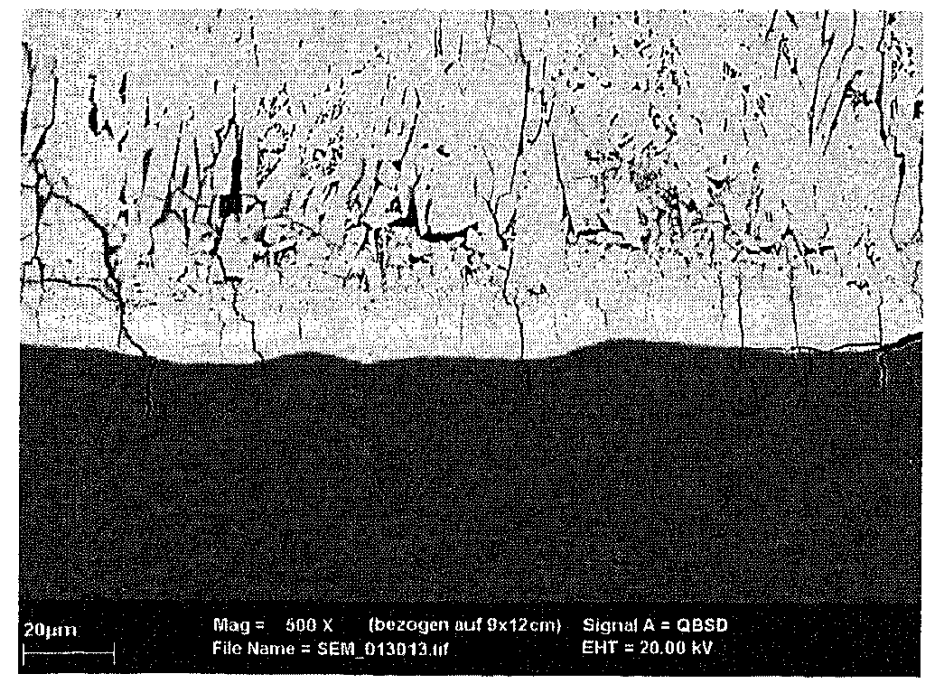

Bild 14. Saum mit Fremdmetalleinschlüssen in der Zinkschicht (hell)

Fig. 14. Zone containing foreign metallic inclusions in the zinc coating(light coloured) 


\section{Diskussion}

Wie an den Beispielen gezeigt wurde, ist das Schadensgeschehen bei feuerverzinkten Konstruktionen komplex. Im Rahmen dieser $\mathrm{Zu}$ sammenstellung konnten lediglich einige Aspekte angesprochen werden. Bestimmt gibt es zahllose weitere, wichtige Einflussgrössen, wie beispielsweise die Eintauchbedingungen in das Zinkbad oder das Beizen, auf die hiernicht näher eingegangen wurde. Allen hier geschilderten Schadensfällen ist gemeinsam, dass es sich beim verwendeten Werkstoff um einen relativ hochfesten Baustahl vom Typus S355 handelte. Es kann sich hierbei zwar um einen Zufall handeln. Es ist aber bekannt, dass der Angriff der Zinkschmelze auf den Stahl bei höheren Kohlenstoffgehalten und folglich höheren Festigkeiten zunimmt und damit die Gefahr der Flüssigmetallversprödung ansteigt [4]. Zur Vermeidung von Schäden in Fertigungsprozessen mit Feuerverzinken ergeben sich zahlreiche Ansatzpunkte. Bereits bei der Konstruktion können ungünstige Spannungskonzentrationen vermieden werden. Sollen die Bauteile kalt umgeformt werden, ist es empfehlenswert, bei der Stahlbestellung auf diesen Umstand hinzuweisen und der chemischen Zusammensetzung entsprechendes Gewicht beizumessen. Die Verzinkungsbetriebe wiederum sollten seitens der Stahlbauer bezüglich fertigungstechnischer Besonderheiten informiert werden. Die Überwachung der Zinkbäder hinsichtlich der chemischen Zusammensetzung ist für einen störungsfreien Betrieb unerlässlich. Der Problematik der repräsentativen Probenentnahme muss hierbei aber Rechnung getragen werden. Da die Risse teilweise verborgen sind, könnte bei sicherheitsrelevanten Bauteilen zumindest eine stichprobenweise Rissprüfung, beispielsweise mittels Ultraschall, vorgesehen werden.

\section{Literatur/References}

[1] W. Rädeker, Der interkristalline Angriff von Metallschmelzen auf Stahl, Werkstoffe und Korrosion 10/1973.

[2] W. Friehe, Dehnungsinduzierte Spannungsrisskorrosion in Flüssigmetallen, Werkstoffe und Korrosion 29/1978.

\section{Discussion}

As has been shown by the examples, failures in hot dipped galvanised components can be complex. Within the scope of this article only a few of the aspects involved have been addressed. There are certainly numerous other important effects such as the immersion conditions in the zinc bath or the pickling of the steel before galvanising, which have not been discussed. All of the failures presented however have one thing in common. In each case the steel used was a relatively high strength structural steel of the type $\mathbf{3 5 5}$. It may be a coincidence, but it is known that the attack of steels by molten zinc increases as the carbon content, and hence the tensile strength of the steel increases, and that the danger of liquid metal embrittlement also increases [14]. There are numerous points which need to be taken into account in order to prevent such failures during hot dip galvanising. As early on as during the fabrication of the steelwork, unfavourable stress concentrations should be avoided. If the components are to be cold formed it is recommended that this be noted on the purchase order for the steel and that particular importance be laid on the chemical composition of the steel. The galvaniser should also be informed by the steel fabricator of any particular details involved in the fabrication of the steelwork. Good control of the zinc bath, and in particular of it's chemical composition, is essential for problem free operation. The difficulty of taking representative samples of the bath for chemical analysis must be realised. As in many cases any cracking which might occur may be hidden to the naked eye, it is essential that a respresentative sample of all safety critical components and fabrications be subjected to non-destructive testing after galvanising, for example using ultrasonic methods.
[3] Tsuneo Ishida, The Reaction of Solid Iron with Molten Tin, Japan Inst. Metals, 35, $1971,958$.

[4] Handbuch Feuerverzinken, VEB Deutscher Verlag für Grundstoffindustrie, Leipzig, 1970. 